\title{
IMPLEMENTATION OF TGT LEARNING MODEL TO IMPROVE LEARNING ACTIVITIES AND STUDY RESULTS
}

\author{
Sulistyo Widodo \\ SMA Negeri 1 Kediri \\ Email:widodo98@gmail.com
}

\begin{abstract}
Abstrak, This Classroom Action Research (CAR) aimed to know how the implementation of TGT Learning Model can improve the learning activities and study results of the students of class X MIPA H. SMAN 1 Kediri, This students learning activities at the first cycle was $46.8 \%$ and the second cycle was $69.28 \%$, The study results at the first cycle was $33.33 \%$ and the second cycle was $83.33 \%$. It can be concluded that TGT Learning Model can improve the learning activities and study results.
\end{abstract}

Keywords :TGT model, learning activity, study result.

\section{PENDAHULUAN}

Dunia pendidikan kita kurang memberikan kesempatan kepada siswa dalam perbagai mata pelajaran untuk mengembangkan kemampuan berfikir holistik (menyeluruh), kreatif, objektif dan logis. Pendekatan dalam pembelajaran masih terlalu didominasi oleh peran guru (teacher centered). Guru lebih banyak menempatkan siswa sebagai objek dan bukan sebagai subjek didik, serta kurang memperhatikan ketuntasan belajar secara individual. Model pembelajaran yang tradisional ini kurang menarik minat siswa dalam mempelajari suatu pelajaran. Salah satu upaya yang dilakukan oleh pemerintah untuk meningkatkan mutu pendidikan adalah melalui penerapan kurikulum 2004 sebagai penyempurnaan kurikulum sebelumnya. Dalam kurikulum ini proses pembelajaran berlangsung alamiah dalam bentuk kegiatan siswa bekerja dan mengalami, bukan transfer pengetahuan dari guru ke siswa. Disini siswa perlu mengerti makna belajar, manfaat dan cara mencapai keberhasilan. Penilaian dalam kurikulum 2004 tidak hanya menitik beratkan pada penilaian ranah kognitif, tetapi juga memperhatikan ranah afektif dan psikomotor. Ranah kognitif berhubungan dengan kemampuan berfikir, ranah afektif mencangkup watak perilaku, sedangkan ranah psikomotor berhubungan dengan aktifitas fisik.

Ranah afektif menentukan keberhasilan belajar seseorang. Orang yang tidak memiliki minat pada pelajaran tertentu sulit untuk mencapai keberhasilan studi secara optimal. Seseorang yang berminat dalam suatu mata pelajaran diharapkan akan mencapai hasil pembelajaran yang optimal.
Oleh karena itu, guru harus mampu membangkitkan minat semua peserta didik dalam belajar mata pelajaran yang menjadi tanggung jawab guru.

Salah satu prinsip penting dari psikologi pendidikan adalah guru tidak boleh hanya sematamata memberikan pengetahuan kepada siswa. Siswa harus membangun pengetahuan didalam benaknya sendiri. Guru dapat membantu proses ini dengan cara membuat informasi menjadi sangat bermakna dan sangat sesuai bagi siswa dengan memberikan kesempatan pada siswa untuk menemukan atau menerapkan ide-idenya sendiri. Dengan demikian guru menerapkan pengajaran yang terpusat pada siswa (student centered instruction), peranan guru adalah membantu siswa menemukan fakta, konsep atau prinsip bagi diri meraka sendiri, bukan ceramah atau mengendalikan seluruh kegiatan di kelas.

Siswa memiliki derajat potensi, latar belakang historis, serta harapan masa depan yang berbeda-beda. Karena adanya perbedaan tersebut manusia dapat saling mencerdaskan, sehingga sumber belajar siswa bukan hanya guru dan buku ajar, tetapi juga sesama siswa [1].Dewasa ini telah dikembangkan strategi pembelajaran yang dikenal dengan nama Contextual Teaching and Learning (CTL) yang intinya membantu guru untuk mengaitkan materi pelajaran dengan kehidupan nyata dan memotivasi siswa untuk mengkaitkan pengetahuan pelajaran yang dipelajarinya dengan kehidupan mereka.

Ada berbagai strategi pengajaran yang berasosiasi dengan pembalajaran Kontektual (CTL) diantaranya adalah pembelajaran kooperatif. Dalam pembelajaran kooperatif, guru menciptakan suasana yang mendorong siswa untuk saling membutuhkan 
sehingga terjadi hubungan saling ketergantungan yang bersifat positif. Hal ini menuntut adanya interaksi yang memungkinkan sesama siswa saling memberikan motivasi untuk meraih hasil belajar yang optimal, selain itu salah satu keunggulan pembelajaran kooperatif adalah mengembangkan kegembiraan belajar yang sejati [2]

Pembelajaran kooperatif terbagi menjadi beberapa tipe, diantaranya tipe TGT (Team Game Tournament) yaitu pembelajaran kooperatif yang hampir sama dengan tipe STAD (Student Team Achievement Division) yang dilengkapi dengan pertandingan akademis yang mana setiap kelompok mempunyai kemampuan yang sama (Wawang, 2000).

Selama ini pembelajaran Kimia di SMA Negeri 1 Kediri selalu menggunakan metode ceramah dan tanya jawab, sehingga tanpa variasi dan kurang menarik minat siswa, untuk itu perlu adanya upaya untuk meningkatkan minat belajar siswa pada mata pelajaran Kimia di SMA Negeri 1 Kediri. Upaya tersebut mendorong peneliti untuk melakukan penelitian tindakan kelas dengan judul "Peningkatan Minat Belajar Mata Pelajaran KIMIA melalui model pembelajaran Kooperatif tipe TGT" di SMA Negeri 1 Kediri.

\section{METODE PENELITIAN}

Penelitian ini adalah Penelitian Tindakan Kelas (PTK) atau Classromm Action Research (CAR) dengan subjek penelitian adalah siswa kelas $\mathrm{X}$ MIPA $\mathrm{H}$ yang berjumlah 35 anak.

Penelitian dilakukan di SMA Negeri 1 Kediri yang terletak di Jalan Veteran No. 1 Kediri lebih kurang $3 \mathrm{~km}$ daripusatkota. Lingkungan sekitar sekolah merupakan perumahan penduduk dengan tingkat ekonomi menengah keatas.

\section{Siklus 1}

\section{Tahap Perencanaan}

a. Mencari informasi awal mengenai masalah yang dihadapi siswa pada mata pelajaran kimia.

b. Mendatangi lokasi penelitian.

c. Mewawancarai guru kimia mengenai hasil belajar siswa.

d. Berkonsultasi dengan guru kimia mengenai suyek, waktu dan materi.

e. Pertemuan awal dengan siswa.

f. Menyusun perangkat pembelajaran.

\section{Tahap Pelaksanaan}
a. Melaksanakan pembelajaran berdasarkan RPP
b. Mengisi lembar observasi aktivitas siswa, keterlaksanaan pembelajaran oleh observer.
c. Mengamati aktivitas siswa selama pembelajaran

\section{Tahap pengamatan/observasi}

a. Proses pengamatan dilakukan oleh dua orang observer.

b. Mengevaluasi siswa dengan materi yang telah disampaikan

c. Menganalisis data hasil observasi dan hasil evaluasi siswa.

\section{Tahap refleksi}

Refleksi dilakukan setelah siklus 1 selesaim dan digunakan sebagai acuan untuk merencanakan tindakan pada siklus selanjutnya.

\section{Teknik Pengumpulan data}

Teknik pengumpulan data menggunakan lembar pengelolaan pembelajaran tipe TGT, lembar observasi respondan lembar observasi minat

\section{Teknik Analisis Data}

Dalam penelitian ini diperlukan empat macam intrumen pengamatan yaitu untuk mengamati :

a. Pengelolaan kegiatan pembelajaran dengan menggunakan lembar pengamatan pengelolaan pembelajaran kooperatif tipe TGT.

b. Respon siswa terhadap kegiatan pembelajaran dengan menggunakan lembar observasi respon siswa terhadap kegiatan pembelajaran.

c. Minat siswa sebelum dan selama penelitian dengan menggunakan lembar observasi minat siswa.

d. Ketuntasan belajar siswa melalaui analisis pencapaian hasil belajar

\section{Indikator keberhasilan}

Penelitian dikatakan berhasil jika terjadi peningkatan minat siswa, respon siswa dan ketuntasan belajar siawa.

\section{HASIL DAN PEMBAHASAN}

Penelitian ini berlangsung dalam dua siklus.Pada bagian ini siswa dikenalkan dengan model pembelajaran kooperatif tipe TGT agar nantinya pada pelaksanaan penelitian yang sesungguhnya siswa tidak merasa canggung lagi. 
Sehingga diharapkan nanti pada saat penelitian suasana kelas dapat alami.

Siswa tidak merasa kalau sedang diteliti atau sedang ada penelitian. Siswa dibiasakan untuk bergabung dengan kelompoknya serta bekerja sama dengan anggota kelompoknya. Kemudian setelah siswa dianggap sudah bisa bergabung dan bekerja secara kelompok peneliti memberikan angket respon siswa terhadap pelajaran kimia yang antara lain berisi alasan mereka sekolah di SMA ini, pelajaran yang disukai/tidak disukai, tanggapan mereka tentang pelajaran kimia dan harapannya, serta nilai kimia yang telah didapatkannya selama ini memuaskan/tidak.

\section{Data Hasil Observasi}

\section{Siklus Pertama \\ 1. Perencanaan}

Pada bagian ini siswa dikenalkan dengan model pembelajaran kooperatif tipe TGT agar nantinya pada pelaksanaan penelitian yang sesungguhnya siswa tidak merasa canggung lagi. Sehingga diharapkan nanti pada saat penelitian suasana kelas dapat alami. Siswa tidak merasa kalau sedang diteliti atau sedang ada penelitian. Siswa dibiasakan untuk bergabung dengan kelompoknya serta bekerja sama dengan anggota kelompoknya. Kemudian setelah siswa dianggap sudah bisa bergabung dan bekerja secara kelompok peneliti memberikan angket respon siswa terhadap pelajaran kimia yang antara lain berisi alasan mereka sekolah di SMA ini, pelajaran yang disukai/tidak disukai, tanggapan mereka tentang pelajaran kimia dan harapannya, serta nilai kimia yang telah didapatkannya selama ini memuaskan/tidak.

Kemudian guru menyiapkan tugas mempelajari Bab Struktur Atom dan Sistem Periodik yang akan diberikan kepada siswa termasuk menyiapkan Kartu Soal sederhana yang akan digunakan untuk Tournament di kelas.

Kartu Soal, yang akan digunakan oleh siswa dalam tournamen telah disediakan pada masing masing meja game. Hal ini bertujuan agar siswa dalam melakukan tuornamen menjadi lebih mudah menggorganisasi kerja siswa dalam suatu kelompok atau tim.

Guru melaksanakan kegiatan pembelajaran sesuai dengan skenario yang telah direncanakan dalam RP-1 . Sebelum kegiatan inti, siswa diberikan Pretest untuk mengetahui sejauh mana prasyarat yang ditetapkan telah dimiliki dalam pengetahuan siswa. Pada akhir Kegiatan Pembelajaran siswa diberikan Post test untuk mengevaluasi sejauh mana keberhasilan proses pembelajaran yang telah dilakukan oleh guru melalui " Game Tournament ".

\section{Pelaksanaan}

Guru menyampaikan tujuan pembelajaran yang akan dicapai serta memberi motivasi kepada siswa. Berikutnya guru membentuk kelompok heterogen yaitu berdasarkan kemampuan akademik serta jenis kelamin.

Kemudian setelah siswa bergabung dengan kelompok masing-masing, guru membagikan Kartu Tornamen yang digunakan untuk pertandingan atau game. Sambil membagi Kartu Soal, guru meneliti kelengkapan alat yang dibawa siswa untuk pelaksanaan tournamen.

Pada saat pelaksanaan siklus pertama kegiatan pembelajaran secara umum berjalan sesuai dengan skenario yang telah dirumuskan dalam Rencana Pembelajaran ( RP-1). Waktu yang yang telah ditetapkan $2 \times 45$ menit ternyata masih belum menuntaskan kegiatan pembelajaran. Tercatat tambahan waktu beberapa menit yang dibutuhkan untuk menyelesaikan beberapa meja pertandingan yang belum tuntas turnamennya.

Dalam kegiatan pembelajaran melalui Kooperatif Tipe TGT ini secara umum siswa telah bekerja dengan baik hingga dapat menyelesaikan tugasnya dan masing masing siswadalam satu meja turnamen dapat menjalankan perannya masing masing dengan baik. Soal soal yang terdapat dalam Kartu Soal pada tournamen telah terjawab dengan benar. Validasi perolehan skor pada masing masing meja game telah dilaksanakan dengan baik oleh siswa hingga telah diperoleh peringkat skor antar masing masing kelompok meja pertandingan.

\section{Pengamatan}

Berdasarkan kegiatan yang sudah dilaksanakan antara lain dengan memberi tugas rumah yaitu mempelajari tentang Struktur Atom dan Sistem Periodik, siswa lebih siap melaksanakan kegiatan belajar di kelas. Pada awalnya siswa ragu seandainya tidak bisa menjawab soal pada saat berlangsungnya tournamen, tetapi setelah berlangsung pertandingan beberapa menit mereka tidak ragu lagi karena masing masing orang dalam satu meja pertandingan tidak lagi gugup dalam menjawab soal apabila telah sampai gilirannya menjawab. Selama kegiatan tournamen sebagian besar siswa aktif melaksanakannya. Namun masih ada juga beberapa anak yang belum aktif. Selama ini siswa belum pernah melakukan pembelajaran dengan melakukan suatu tornamen melalui 
pertanyaan dalam kartu soal yang dibuat dari'Kartu Remi ".,

Siswa kelihatannya bersemangat sekali dalam melaksanakan tournamen dengan seringkali siswa bertanya apabila ada hal yang belum dipahaminya mengenai aturan main dalam "pertandingan" tersebut.

Siswa merasa senang ternyata mereka dapat belajar kimia dengan menggunakan kartu yang digunakan untuk menempelkan butir soal soal yang dipertandingkan dalam tornamen tersebut. Setelah dilaksanakan validasi jawaban dari permasalahan yang ada Kartu Soal siswa menjadi lebih paham sehingga ketika guru menyampaikan pada kesempatan mendatang jika diadakan pembelajaran Kooperatif Tipe TGT mereka menjawab "Yes". Dari hasil ulangan yang dilaksanakan hasilnya diperingkat secara kelompok. Dengan adanya penghargaan kelompok suasana kelas menjadi semakin hidup dan anak-anak kelihatan senang. Secara umum pengelolaan pembelajaran yang dilakukan guru adalah baik dan sebagian besar kegiatan pembelajaran berpusat pada diri siswa. Guru lebih banyak membimbing siswa dalam pelaksanaan game tersebut pada kelompok pertandingan. [3]

Hasil pengamatan terhadap pengelolaan pembelajaran pada setiap siklus pertama menggunakan instrumen 1 , yang rincian perhitungan reliabilitas Instrumen pengelolaan pembelajaran Kooperatif Tipe TGT dapat dilihat pada lampiran. Secara sederhana dan ringkas pengolahan data instrumen pengelolaan pembelajaran dapat dilihat pada tabel1 sebagai berikut.

Tabel 1 Penilaian Pengelolaan Pembelajaran TGT Siklus 1.

\begin{tabular}{clcc} 
No. & $\begin{array}{l}\text { Aspek } \\
\text { diamati }\end{array}$ & $\begin{array}{c}\text { yang } \\
\text { Rata } \\
\text { rata } \\
\text { Skor }\end{array}$ & Kategori \\
\hline 1. & Pendahuluan & 3,00 & Baik \\
\hline 2. & Kegiatan inti & 3,00 & Baik \\
\hline 3. & Kegiatan Penutup & 3,00 & Baik \\
\hline 4. & Pengelolaan waktu & 3,00 & Baik \\
\hline 5. & $\begin{array}{l}\text { Pengamatan } \\
\text { suasana kelas }\end{array}$ & 3,00 & Baik \\
\hline
\end{tabular}

Berdasarkan data di atas pada umumnya siswa sudah mampu menerapkan kegiatan dengan baik. Pengolahan data angket tentang Respon Siswa dalam KBM secara terperinci tercantum dalam lampiran . Secara ringkas pengolahan angket tentang Respon Siswa dalam KBM dapat dilihat pada tabel 4.2 sebagai berikut :

Tabel 2 Respon Siswa siklus 1

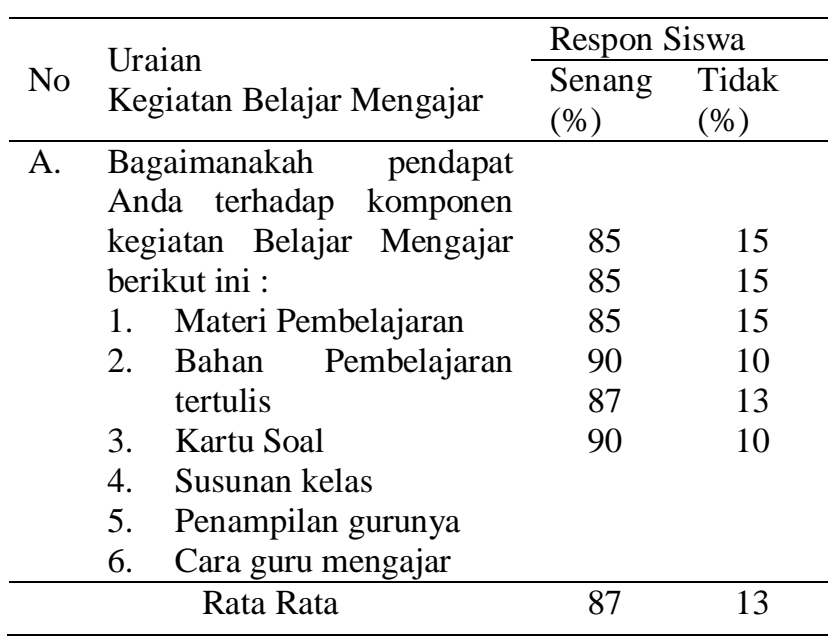

Secara keseluruhan $87 \%$ siswa menyatakan senang terhadap kegiatan pembelajaran yang dilakukan oleh guru.

\section{Refleksi}

Ada beberapa hal yang dapat direfleksikan dari hasil kegiatan pada siklus pertama antara lain :1. Beberapa siswa yang pada saat turnamen menggunakan kartu soal masih kurang memahami secara benar tentang perannya masing masing dalam menjalankan pertandingan. Pada siklus kedua perlu ditekankan lagi tentang aturan pertandingan secara benar pada maing masing siswa sebelum turnamen dimulai. Sehingga kendala kelancaran giliran antar siswa dapat tercipta dan berlangsung secara tertib dan dapat mengefektifkan waktu yang digunakan.

2. Siswa kurang terampil dalam mengacak kartu soal serta pembagian peran.

3. Masih ada beberapa siswa yang belum mau aktif dalam kegiatan pada meja pertandingan .

4.Alokasi waktu yang ditetapkan tidak dapat mencukupi segala kegiatan pembelajaran yang telah direncanakan. [4]

\section{Siklus Kedua \\ 1. Perencanaan}

Dengan melihat hasil refleksi dari Siklus pertama maka pada Siklus kedua ini siswa lebih banyak akan dilatih untuk simulasi kegiatan turnamen serta siswa banyak diaktifkan dalam kegiatan kelompoknya. Guru memberikan tekanan tentang pentingnya penguasaan materi sbelum pertandingan " Meja Turnamen " dimulai. Pada siklus kedua ini tetap diadakan tes awal untuk 
mengetahui kesiapan dan pemahaman siswa tentang materi yang akan diujikan pada turnamen nanti. Kemudian disiapkan juga soal untuk ulangan harian yang kedua. Penggunaan waktu yang harus diefektifkan agar Rencana Pembelajaran pada siklus kedua dapat berlangsung sesuai yang diharapkan.

\section{Pelaksanaan}

Pada pelaksanaan kegiatan belajar mengajar di siklus yang kedua guru menyebutkan tujuan pembelajaran serta memotivasi siswa agar lebih giat dan aktif dalam kegiatan belajarnya. Karena materi yang dihadapinya lebih rumit jika dibandingkan dengan Siklus pertama. Setelah itu diadakan tes awal untuk mengetahui pengetahuan siswa tentang materi yang telah dirangkumnya. Sebelum siswa melaksanakan praktikum di laboratorium siswa diberi pengarahan agar selama turnamen tetap menjaga dan menjujung tinggi sportifitas dan harus bersifat jujur karena bagaimanapun hasil akhir pada turnamen adalah nilai kebersamaan yang diutamakan. Kemudian siswa disuruh bergabung dengan kelompoknya kembali untuk mendapatkan penghargaan kelompok atau team. Setelah kegiatan selesai, masing-masing kelompok secara bergantian memnerima penghargaan yang telah disiapkan oleh guru. Kemudian guru melakukan validasi jawaban. Mengakhiri pelajaran pada hari itu siswa diberi pekerjaan rumah yang juga dibahas pada pertemuan berikutnya. Kemudian pada pertemuan berikutnya diadakan Ulangan Harian kedua dan diberi penghargaan untuk kelompok yang memperoleh rata-rata nilai terbaik. Penghargaan kelompok didasarkan pada hasil ulangan harian kedua.ada pergantian

\section{Pengamatan}

Secara umum ketrampilan siswa dalam melaksanakan kegiatan praktikum ada peningkatan. Walaupun masih ada kendala ketika mereka harus mengkonversikan suhu dari Celcius ke Kelvin. Dalam bekerjasama dengan kelompoknya siswa sudah mulai banyak aktif terlibat. Jika dibanding siklus pertama. Untuk pengelolaan proses belajar mengajarnya guru secara umum adalah baik. Penghargaan kelompok menambah hangat suasana kelas.Hasil pengamatan terhadap pengelolaan pembelajaran pada siklus kedua, yang rincian perhitungan reliabilitas Instrumen pengelolaan pembelajaran kooperatif Tipe TGT dapat dilihat pada lampiran. Secara sederhana dan ringkas pengolahan data instrumen pengelolaan pembelajaran dapat dilihat pada tabel 3 berikut ini.
Tabel 3 Penilaian Pengelolaan Pembelajaran TGT Siklus 1.

\begin{tabular}{clcl}
\hline No. & Aspek yang diamati & $\begin{array}{c}\text { Rata } \\
\text { rata } \\
\text { Skor }\end{array}$ & Kategori \\
\hline 1. & Pendahuluan & 3,50 & Baik \\
\hline 2. & Kegiatan inti & 3,50 & Baik \\
\hline 3. & Kegiatan Penutup & 3,50 & Baik \\
\hline 4. & Pengelolaan waktu & 3,00 & Baik \\
\hline 5. & $\begin{array}{l}\text { Pengamatan suasana } \\
\text { kelas }\end{array}$ & 3,00 & Baik \\
\hline
\end{tabular}

Berdasarkan Tabel 3 tersebut menunjukkan bahwa skor rata-rata untuk tiap aspek yang diamati pada kegiatan pembelajaran Kooperatif Tipe TGT adalah baik. Jika pada siklus pertama pada aspek pengelolaan waktu kurang, maka pada siklus kedua ada peningkatan, yaitu kategori baik. Guru dapat mengoperasikan pembelajaran dengan lebih baik jika dibandingkan pada siklus sebelumnya dan siswa menjadi lebih semangat dan antusias dalam mengikuti kegiatan pembelajaran. Terjadi peningkatan skor rata rata pada tiga aspek yang diamati, yaitu Pendahuluan, kegiatan inti dan pengelolaan waktu yang meningkat cukup signifikan dari siklus sebelumnya.

Pengamatan terhadap kegiatan turnamen di masingmasing meja pertandingan berjalan lebih lancer dan turnamen berlangsung dengan sportifitas yang tinggi dan siswa menikmati benar pertandingan antar kelompok yang terwakili pada masing-masing meja turnamen tersebut. [5]

Minat dan respon siswa terhadap Kegitan Belajar Mengajar (KBM) dapat diperoleh melalui angket siswa dengan menggunakan instrumen 3 . Angket yang dibagikan oleh siswa yang telah dijawab secara jujur dan objektif diolah secara kualitatif dengan prosentase .Pengolahan angket tentang Respon Siswa dalam KBM pada siklis kedua secara terperinci tercantum dalam lampiran. Secara ringkas pengolahan angket tentang Respon Siswa dalam KBM dapat dilihat pada tabel 4 sebagai berikut : 
Tabel 4. Respon Siswa pada Siklus 2

\begin{tabular}{llcc}
\hline & \multicolumn{1}{c}{ Uraian } & \multicolumn{2}{c}{ Respon Siswa } \\
\cline { 3 - 4 } No & Kegiatan Belajar Mengajar & $\begin{array}{c}\text { Senang } \\
(\%)\end{array}$ & $\begin{array}{c}\text { Tidak } \\
(\%)\end{array}$ \\
\hline A. & Bagaimanakah pendapat & & \\
Anda terhadap komponen & & \\
kegiatan Belajar Mengajar & & \\
berikut ini : & 90 & 10 \\
1. Materi & 90 & 10 \\
2. Bahan tertulisnya & 90 & 10 \\
3. Lembar Kerja Siswa & 90 & 10 \\
4. Susunan kelas & 90 & 10 \\
5. Penampilan gurunya & 90 & 10 \\
6. Cara guru mengajar & \multicolumn{2}{c}{10} \\
\hline & RATA RATA \% & 90 & 10 \\
\hline Berdasarkan hasil pengolahan & angket
\end{tabular}

respon siswa terhadap kegiatan pembelajaran pada siklus kedua, dari keenam komponen yang ditanyakan empat diantaranya (67\%) mengalami peningkatan dibandingkan pada siklus sebelumnya. Sehingga secara komprehensif, model pembelajaran kooperatif tipe TGT sangat disenangi oleh $90 \%$ siswa. Apabila ditanyakan kepada siswa, apakah mereka berminat mengikuti kegiatan KBM seperti yang pernah diberikan,Semua siswa (100\%) menyatakan" ya".

Berdasarkan data dari pengamat 1 dan 2 secara umum bahwa guru sudah dapat menerapkan model pembelajaran kooperatif tipe TGT dengan baik. Dibandingkan pada siklus sebelumnya, pada siklus kedua ada peningkatan yang signifikan tentang pengelolaan waktu,sehingga semua skenario pembelajaran dapat terlaksana sesuai rencana waktu yang tersedia.Semangat dan antusias siswa meningkat disamping juga ada peningkatan keterampilan siswa memainkan kartu soal yang berupa kartu remi dengan bagian halaman sebelahnya ditempeli butir soal.

\section{Refleksi}

Dari perlakuan yang ada ternyata ada peningkatan kemampuan siswa yang dalam arti siswa lebih memahami perannya masing masing dalam melakukan pertandingan pada setiap meja turnamen.Secara alami mereka bertanding dalam suasana yang menyenangkan disamping tetap berjuang menjadi yang terbaik dalam menjawab soal untuk mengumpulkan skor. Hanya saja masih ada salah pengertian untuk menjawab soal lemparan pada giliranya. Untuk hasil ulangan harian ada peningkatan ketuntasan siswa yang cukup signifikan. Dari 44 siswa yang mengalami ketuntasan sekitar 35 orang siswa. Siswa pada umumnya senang dengan model pembelajaran yang dilakukan selama penelitian ini.

Dibandingkan pada siklus sebelumnya, pada siklus kedua ada peningkatan yang signifikan tentang pengelolaan waktu,sehingga semua skenario pembelajaran dapat terlaksana sesuai rencana waktu yang tersedia. Semangat dan antusias siswa meningkat disamping juga ada peningkatan keterampilan proses siswa.

\section{Pembahasan}

Hasil pengamatan terhadap pengelolaan pembelajaran pada setiap siklus dengan menggunakan istrumen, pengamatan dilakukan oleh dua orang guru kolaboran saat kegiatan pembelajaran berlangsung. Data dari Rp-1 (siklus1) dan RP-2 (Siklus-2) dijumlah, diambil rata-rata dan ditentukan kategorinya. Secara ringkas hasil pengolahan data ini dapat dilihat pada Tabel 5 berikut :

Tabel 5 Penilaian Pengelolaan Pembelajaran melalui model Pembelajaran tipe TGT

\begin{tabular}{|c|c|c|c|c|c|}
\hline \multirow{2}{*}{ No. } & \multirow{2}{*}{$\begin{array}{c}\text { Aspek yang } \\
\text { diamati }\end{array}$} & \multicolumn{2}{|c|}{ Skor tiap RP } & \multirow{2}{*}{$\begin{array}{l}\text { Skor } \\
\text { Rata } \\
\text {-rata }\end{array}$} & \multirow{2}{*}{$\begin{array}{l}\text { Kat } \\
\mathrm{e} \\
\text { gori }\end{array}$} \\
\hline & & RP-1 & $\begin{array}{l}\text { RP } \\
-2\end{array}$ & & \\
\hline 1 & Pendahuluan & 3,33 & $\begin{array}{c}3,6 \\
7\end{array}$ & 3,50 & Baik \\
\hline 2 & Kegiatan inti & 3,13 & $\begin{array}{c}3,6 \\
3\end{array}$ & 3,38 & Baik \\
\hline 3 & Penutup & 3,00 & $\begin{array}{c}4,0 \\
0\end{array}$ & 3,50 & Baik \\
\hline 4 & $\begin{array}{l}\text { Pengelolaan } \\
\text { waktu }\end{array}$ & 3,00 & $\begin{array}{c}3,0 \\
0\end{array}$ & 3,00 & Baik \\
\hline 5 & $\begin{array}{l}\text { Pengamatan } \\
\text { suasana } \\
\text { kelas }\end{array}$ & 3,25 & $\begin{array}{c}3,2 \\
5\end{array}$ & 3,25 & Baik \\
\hline
\end{tabular}

Dari tabel 5 di atas menunjukkan bahwa pada masing-masing aspek yang diamati mempunyai kategori baik. Hal ini berarti kemampuan guru mengelola pembelajaran dengan menggunakan model pembelajaran kooperatif tipe TGT adalah baik, sehingga siswa menjadi tertarik untuk mengikuti pelajaran.

Hal ini terjadi karena ada beberapa siswa yang tidak suka terhadap metode diskusi dan kompetisi dalam turnamen. Namun secara umum ada peningkatan prosentase kesenangan dari RP-1 ke RP-2, yang berarti pula metode yang digunakan berhasil meningkatkan daya tarik siswa terhadap mata pelajaran Kimia. 
Data minat siswa diperoleh dari isian intrumen yang diisi oleh 44 siswa. Data minat siswa terhadap mata pelajaran Kimia secara ringkas disajikan pada Tabel 6

Tabel 6 Minat Siswa Sebelum dan Sesudah Penerapan Model Pembelajaran Kooperatif tipe TGT

\begin{tabular}{llcc}
\hline \multirow{2}{*}{ No. } & Kriteria & \multicolumn{2}{c}{ Prosentase (\%) } \\
\cline { 3 - 4 } & & Sebelum & Sesudah \\
\hline 1 & $\begin{array}{l}\text { Siswa yang } \\
\text { kurang } \\
\text { berminat }\end{array}$ & 25 & 10 \\
\hline 2 & $\begin{array}{l}\text { Siswa yang } \\
\text { berminat }\end{array}$ & 50 & 35 \\
\hline 3 & $\begin{array}{l}\text { Siswa yang } \\
\text { sangat berminat }\end{array}$ & 25 & 55 \\
\hline
\end{tabular}

Dari Tabel 6 nampak bahwa setelah penerapan Model Pembelajaran Kooperatif tipe TGT jumlah siswa yang sangat berminat menjadi meningkat, hal ini menunjukkan bahwa dengan model Kooperatif Tipe TGT siswa mempunyai motivasi yang meningkat sangat signifikan. Siswa yang hanya berminat pada model pembelajaran kooperatif tipe TGT pada kasus ini menjadi berkurang jumlahnya dan mereka kini mejadi kelompok yang sangat berminat. Hal ini terjadi karena untuk siswa yang berminat berdasarkan pendapat mereka, pelajaran kimia dengan model kooperatiftipe TGT sangat menyenangkan yaitu "Belajar sambil Bermain" sehingga sekarang kelompok siswa tersebut menjadi sangat tertarik dan antusias mengikuti pelajaran Kimia.

Data ketuntasan belajar pada setiap sub materi dengan menggunakan model pembelajaran kooperatif tipe TGT diperoleh dari hasil tes setiap individu pada setiap rencana pembelajaran.

Pada Rencana Pembelajaran 1 (RP-1) siswa diberi 5 soal objektif dan 5 soal uraian objektif dengan waktu penyelesaian 45 menit, sedangkan pada Rencana Pembelajaran 2 (RP-2) siswa diberi 5 soal objektif dan 3 soal uraian objektif dengan waktu penyelesaian 35 menit.

Data yang diperoleh kemudian dianalisis melalui analisis pencapaian hasil belajar disetiap rencana pembelajaran. Prosentase ketuntasan belajar siswa diperoleh dengann kriteria tuntas untuk proporsi menjawab benar secara individu minimal $75 \%$. Hasil analisis ketuntasan belajar disajikan pada Tabel 7
Tabel 7 Ketuntasan Belajar Siswa

\begin{tabular}{|c|c|c|c|c|c|}
\hline \multirow{3}{*}{ No. } & \multirow{3}{*}{$\begin{array}{l}\text { Rencana } \\
\text { Pembelaja } \\
\text { ran }\end{array}$} & \multicolumn{4}{|c|}{$\begin{array}{l}\text { Keadaan siswa dalam } \\
\text { ketuntasan belajar }\end{array}$} \\
\hline & & \multicolumn{3}{|c|}{ Jumlahsiswa yang } & \multirow[b]{2}{*}{$\begin{array}{c}\text { Ketun } \\
\text { asan } \\
(\%)\end{array}$} \\
\hline & & $\begin{array}{c}\text { Peser } \\
\text { ta }\end{array}$ & $\begin{array}{l}\text { Tunt } \\
\text { as }\end{array}$ & $\begin{array}{l}\text { Tida } \\
\text { kTu } \\
\text { ntas }\end{array}$ & \\
\hline 1 & RP- 1 & 44 & 25 & 19 & 57 \\
\hline 2 & RP-2 & 44 & 35 & 9 & 80 \\
\hline
\end{tabular}

Dari Tabel 8, Nampak bahwa dengan menggunakan model pembelajaran Kooperatif tipe TGT telah terjadi peningkatan yang cukup signifikan prosentase ketuntasan belajar siswa, hal ini menunjukkan bahwa dengan menggunakan metode pembelajaran ini siswa semakin mampu untuk menguasai materi yang diajarkan.

\section{SIMPULAN DAN SARAN Simpulan}

Berdasarkan hasil analisis data terhadap penelitian perangkat pembelajaran Kimia dengan materi Struktur Atom dan Sistem Periodik di SMA Negeri 1 Kediri yang dilakukan dengan menggunakan 2 (dua) siklus, dapat disimpulkan sebagai berikut:

a. Kemampuan guru dalam mengelola pembelajaran kooperatid tipe TGT adalah baik. Semua yang direncakan dalam pembelajaran berjalan sangat baik sesuai alokasi waktu yang ditentukan.

b. Respon siswa terhadap kegiatan pembelajaran adalah sangat positif. Siswa merasa senang dengan model pembelajaran kooperatif tipe TGT yang dilakukan, sehingga meninghkatkan motivasi dan daya tarik siswa terhadap mata pelajaran Kimia.

c. Minat siswa mengalami peningkatan setelah penerapan model pembelajaran kooperatif tipe TGT

d. Ketuntasan belajar siswa mengalami peningkatan dari siklus 1 ke siklus 2 . Model pembelajaran kooperatif tipe TGT dapat meningkatkan penguasaan siswa terhadap materi yang diajarkan.

\section{Saran}

Memperhatikan hasil penelitian yang diperoleh, maka model pembelajaran kooperatif tipe TGT perlu untuk diterapkan pada sub materi lainnya khususnya materi yang memberikan pemahaman konsep. 


\section{DAFTAR PUSTAKA}

[1] Nurhadi, dkk., 2004, Pembelajaran konstektual dan Penerapan nya dalam KBK, Malang: Universitas Negeri Malang.

[2] Depdiknas, 2003, Pedoman Khusus Pengembangan Silabus dan Penilaian Mata Pelajaran Kimia, Jakarta.

[3] Hoetawarman, Wawang, 2004, Model Pembelajaran Kooperatif. Jaringan Inovasi Pembelajaran

[4] Depdiknas, Dikmenum, 2004, Pedoman Khusus Pengembangan Instrumen dan Penilaian Ranah Afektif. Jakarta.

[5] Depdiknas, Dikmenum, 2004, Pedoman Khusus Pengembangan Intrumen dan Penilaian Ranah Psikomotor, Jakarta. 